\title{
Lipsheim - Rue de la Gare
}

\section{Emmanuel Pierrez}

\section{OpenEdition \\ Journals}

Édition électronique

URL : http://journals.openedition.org/adlfi/8286

ISSN : 2114-0502

Éditeur

Ministère de la culture

\section{Référence électronique}

Emmanuel Pierrez, "Lipsheim - Rue de la Gare », ADLFI. Archéologie de la France - Informations [En ligne], Alsace, mis en ligne le 01 mars 2001, consulté le 25 avril 2019. URL : http://

journals.openedition.org/adlfi/8286

Ce document a été généré automatiquement le 25 avril 2019

(c) Ministère de la Culture et de la Communication, CNRS 


\title{
Lipsheim - Rue de la Gare
}

\author{
Emmanuel Pierrez
}

Opération négative

Le projet de construction de petits collectifs sur un terrain d'une superficie de $4500 \mathrm{~m}^{2}$ près de la gare, est situé à $40 \mathrm{~m}$ au sud d'une nécropole mérovingienne reconnue en 1985 par J.-P. Nassau. Les cinq sondages de diagnostic entrepris se sont révélés négatifs. Le terrain a semble-t-il été excavé sur deux mètres de profondeur puis remblayé. Ces excavations ont oblitéré le terrain le rendant stérile d'un point de vue archéologique.

INDEX

Index géographique : Alsace, Bas-Rhin, Lipsheim

operation Diagnostic (EV)

\section{AUTEURS}

\section{EMMANUEL PIERREZ}

Sous-direction de l'Archéologie 